\title{
COST OPTIMIZATION OF DESALINATION SYSTEM AT NORTHERN COASTAL ZONE OF EGYPT
}

\author{
T. Elgohary
}

Department of Civil Engineering, Heliopolis University, Cairo, Egypt

\section{S. Mansour}

Department of Mechanical Engineering, The Higher Technological Institute, 10th of Ramadan City, Egypt

\begin{abstract}
The coastal zone along Egypt represents a great opportunity for economy, agriculture and industrial activities, this coastal zone suffers from many threats such as sea water intrusion, shore line erosion and sea level rise, these threats will effect on the available water quality especially in agriculture, so, this study was achieved in order to investigate the possibility of using desalination system (Reverse osmosis) for saline ground water in new reclaimed area with affordable price.

Through this study we were able to find out that there is many parameters will effect on the permeate water (desalinated water) such as water temperature, feed water TDS, applied pressure and the energy consumption in form of graphs, in this study we were able to define the performance of such system in such environment by using a graph that represents the distillated cubic meter price versus reclaimed are, we also determined the desalinated water cubic meter price for saline ground water of the Egyptian northern coastal zone, the cubic meter price range is from 4 LE tO 14.67 $L E$ (from $\$ 0$ to $\$ 0.92$ per $\mathrm{m3}$ ). at the end a group of recommendations were deduced.
\end{abstract}

Keywords: Desalination, Coastal zone, Ground aquifer, Cost optimization

Cite this Article: T. Elgohary and M. S. Mansour, Cost Optimization of Desalination System at Northern Coastal Zone of Egypt, International Journal of Civil Engineering and Technology, 11(9), 2020, pp. 1-12.

https://iaeme.com/Home/issue/IJCIET?Volume $=11 \&$ Issue $=9$

\section{INTRODUCTION}

I any country the coastal zone is the coastal region that covers land area up to 200 miles above sea level and water area up to 200 miles below sea level, these coastal zones all over the world have different activities such as fishing, agriculture, industry and tourism, also these coastal zones have urban and rural areas of higher population density[1]. 
Egypt has a large coastal zone that covers almost 650 miles $(1050 \mathrm{~km})$ along the Mediterranean Sea coast line and covers $1941 \mathrm{~km}$ along the red sea coast line as shown in figure 1, Egyptian northern coast zone has very important cities such as Alexandria, Damietta, Marsa Matrouh and Kafr El Sheikh, this coastal zone includes the Nile delta that represents $70 \%$ of the Egyptian industrial and commercial activities[2].

The northern Egyptian coastal zone has some significant ecosystems such as sand dunes, lakes, the Nile river branches, green areas and wet lands, the main water resources in the northern coastal zone are Nile river branches, rain and ground water, the ground water at this zone suffer from sea water intrusion that increase the water salinity, the Egyptian government plans to decrease the stress on the Nile delta by constructing a new urban and rural areas at the west side of the Egyptian northern coastal zone, this will include new land reclamation by using ground water as source for water irrigation for any smart irrigation system, the smart irrigation systems could be drip or sprinkler irrigation system[3].

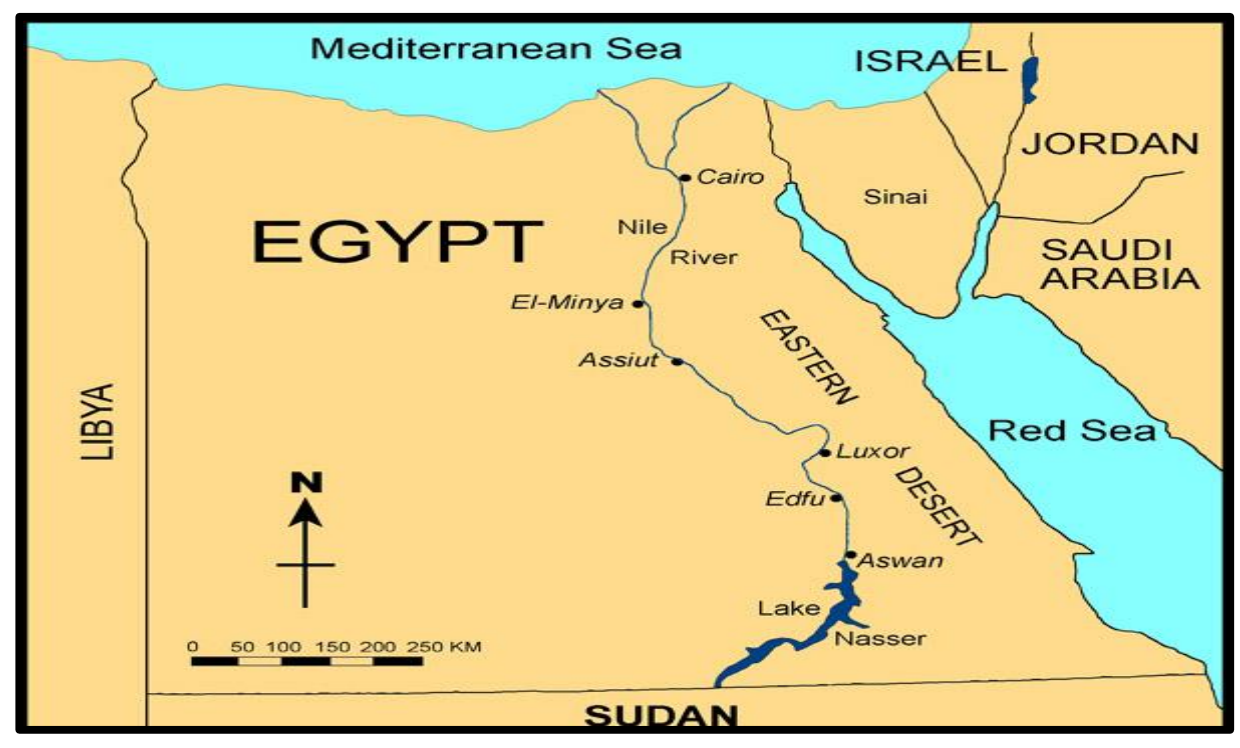

Figure 1 Egypt map shows the Egyptian coast lines [4]

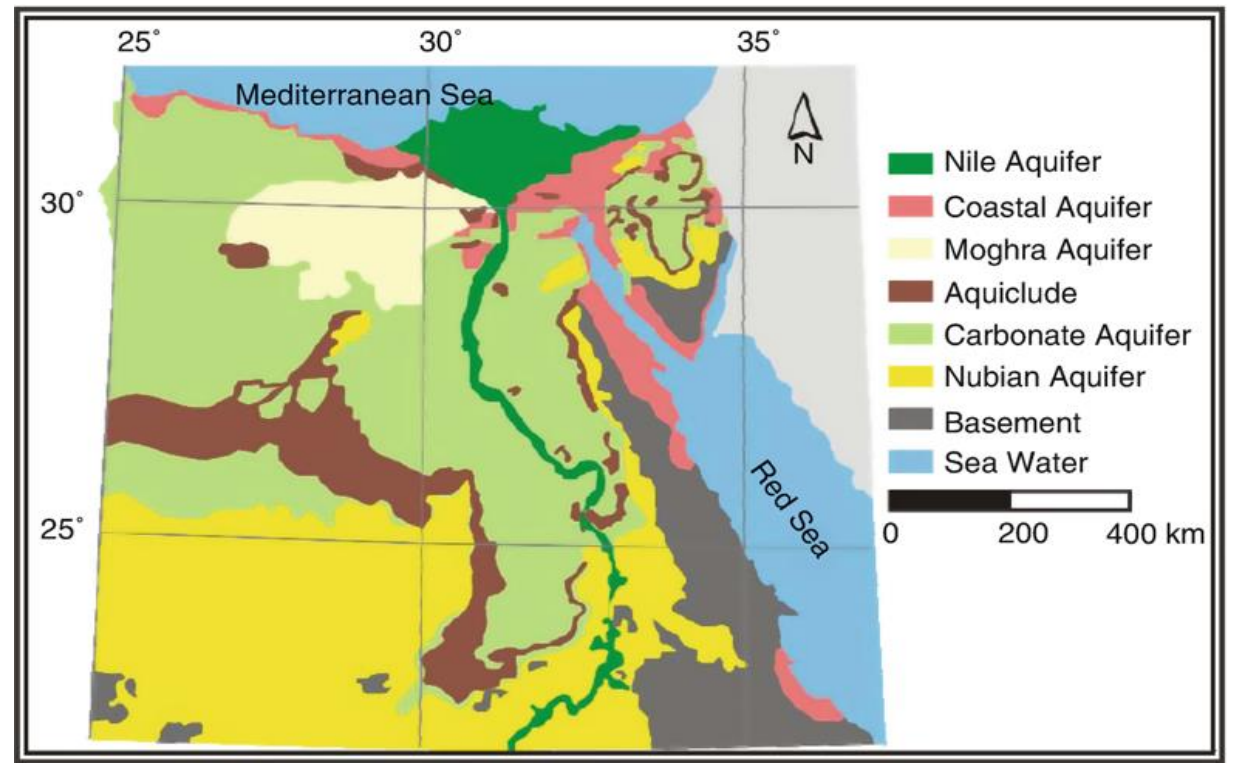

Figure 2 Aquifer map (Egypt) [5] 
Northern Egyptian coastal zone is one of the most promising places for its water potential that can be used to reclaim thousands of acres because it lies entirely on a river of fresh groundwater. Many crops can be cultivated such as date palms and olive trees at these places. However, agriculture faces problems that threaten its survival due to the salinization of the ground water due to sea water intrusion. Egypt has many groundwater aquifers in the coastal zone such as the Moghra aquifer that lies between the West of the Nile Delta and the Qattara Depression, also there is the coastal aquifer on the North-Western coast towards the Qattara depression as shown in figure 2 , both of them are recharged by rainfall. The excess water withdrawal from aquifer increases the water salinity and add another dimension to the irrigation water problem[5].

The coastal aquifer TDS range is from $1288 \mathrm{ppm}$ to $4907 \mathrm{ppm}$ as shown in figure 3 , the aquifer could be considered as shallow aquifer due to the fact that its water table varies from 7 to $25 \mathrm{~m}$ from ground surface, the aquifer is recharged by rain precipitation and from the Nile river seepage, also its TDS is constant along the aquifer depth[6].

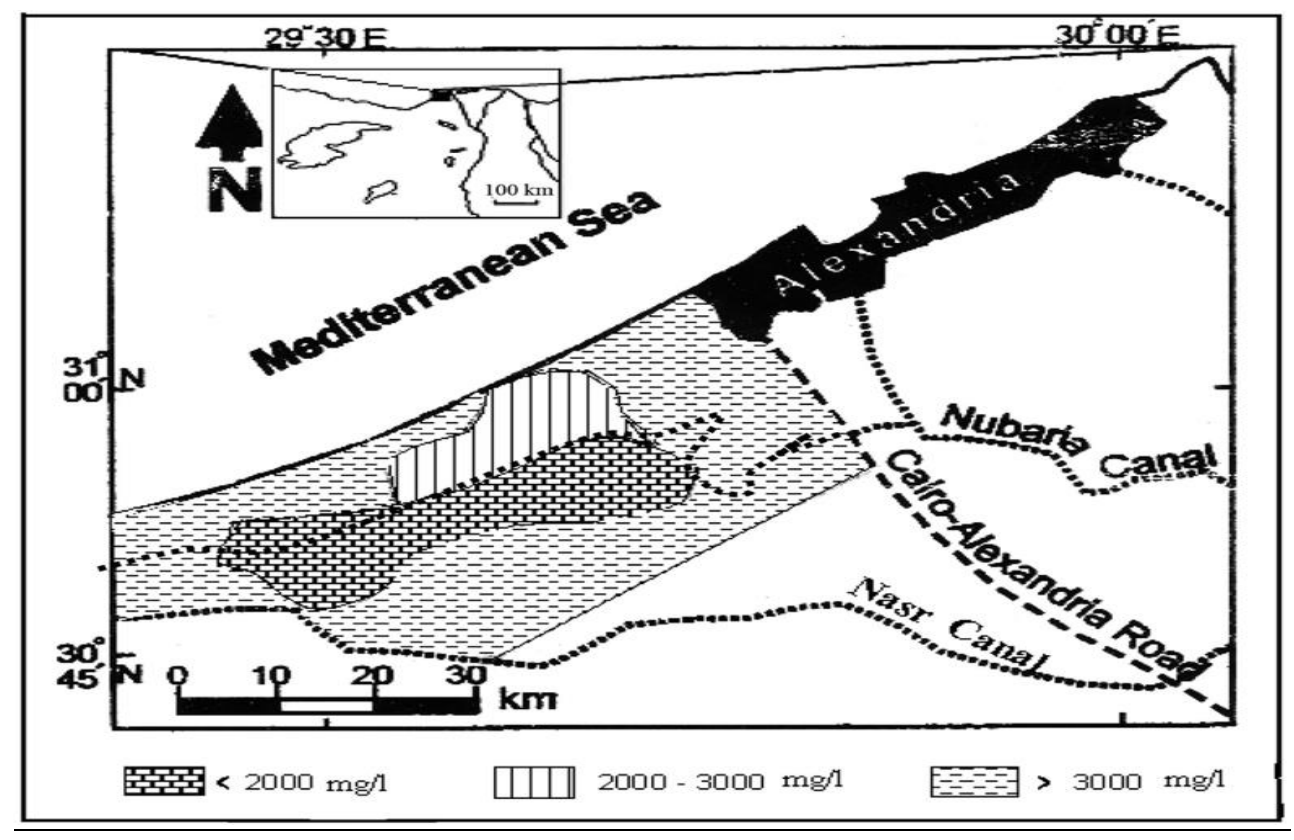

Figure 3 Distribution of salinity content in the coastal aquifer

\subsection{Case of study}

We have chosen farm of area of 5 feddan that have been cultivated with date palm and the required irrigation water is $24 \mathrm{~m}^{3} /$ day/feddan, this farm is located at the western northern coastal zone of Egypt, the water resource for irrigation water is the ground water from the coastal aquifer of salinity varies from $2000 \mathrm{ppm}$ to $5000 \mathrm{ppm}$, and we assumed that in the nearest future the aquifer TDS may reach $10000 \mathrm{ppm}$ under the effects sea level rise, sea water intrusion and water withdrawal stress. The temperature range for this region is shown in table $1[7]$. 
Table 1 The temperature range for the western northern coastal zone of Egypt

\begin{tabular}{cccccc}
\hline Month & $\begin{array}{c}\text { Record high } \\
{ }^{\circ} \mathbf{C}\left({ }^{\circ} \mathbf{F}\right)\end{array}$ & $\begin{array}{c}\text { Average high } \\
{ }^{\circ} \mathbf{C}\left({ }^{\circ} \mathbf{F}\right)\end{array}$ & $\begin{array}{c}\text { Daily mean } \\
\left({ }^{\circ} \mathbf{C}\right)\end{array}$ & $\begin{array}{c}\text { Average low } \\
\left({ }^{\circ} \mathbf{F}\right)\end{array}$ & $\begin{array}{c}\text { Record low }{ }^{\circ} \mathbf{C} \\
\left({ }^{\circ} \mathbf{F}\right)\end{array}$ \\
\hline Jan & 31 & 18.9 & 14 & 9 & 1.2 \\
Feb & 34.2 & 20.4 & 15.1 & 9.7 & 3.6 \\
Mar & 37.9 & 23.5 & 17.6 & 11.6 & 5 \\
Apr & 43.2 & 28.3 & 21.5 & 14.6 & 7.6 \\
May & 47.8 & 32 & 24.9 & 17.7 & 12.3 \\
Jun & 46.4 & 33.9 & 27 & 20.1 & 16 \\
Jul & 42.6 & 34.7 & 28.4 & 22 & 18.2 \\
Aug & 43.4 & 34.2 & 28.2 & 22.1 & 19 \\
Sep & 43.7 & 32.6 & 26.6 & 20.5 & 14.5 \\
Oct & 41 & 29.2 & 23.3 & 17.4 & 12.3 \\
Nov & 37.4 & 24.8 & 19.5 & 14.1 & 5.2 \\
Dec & 30.2 & 20.3 & 15.4 & 10.4 & 3 \\
\hline
\end{tabular}

\section{DESALINATION PLANT (RO)}

In order to irrigate the chosen farm, we decided to irrigate it with water mixture consists of saline water and desalinated one, this was achieved by using the reverse osmosis (RO) desalination method which is the most promising effective desalination technique for a certain capacity. The Reverse Osmosis (RO) desalination plant will work for 24 hours per day by using two pumps for both low and high pressure pumps, each pump of them will work 12 hours per day, through this study we were able to investigate the effect of salt concentration, pressure and temperature on the permeate flow rate, permeate salt concentration (TDS), salt rejection percent and the recovery percent. Therefore, the influence of each of them is adopted in this research to produce an affordable amount of freshwater and to maximize the performance of the present system.

It is worth mention that; we mixed the desalinated water with another saline water in order to produce a water mixture of TDS of $2000 \mathrm{ppm}$, this degree of salinity is suitable for some crops that can tolerate high rate of salinity levels up to $2000 \mathrm{ppm}$ according to FAO standards [8]. Economic benefit will be achieved by increasing the productivity of the required water with minimum energy consumption (i.e. decreasing the required pressure needed to complete the process of separating the salts inside the RO membrane to overcome the osmotic pressure), the highest productivity of fresh water will lead to the lowering of freshwater cubic meter price.

\subsection{Experimental Apparatus}

Figure 4 shows the reverse osmosis (RO) desalination plant and its different elements, it consists of The apparatus consists of pretreatment part that includes low pressure pump (feed pump) to deliver water to multimedia filter in order to remove particles greater than 20 microns, there is also in this part a cartridge filters to remove particles greater than 1 micron and to remove organic matter, after that the salty water passes through the membrane by the help of the high pressure pump in order to remove salts from water, the permeate flow goes to fresh water tank while the brine goes to drain, there are different additional devises such as control valves and measuring instruments, figure 5 represents schematic diagram for the apparatus[9]. 


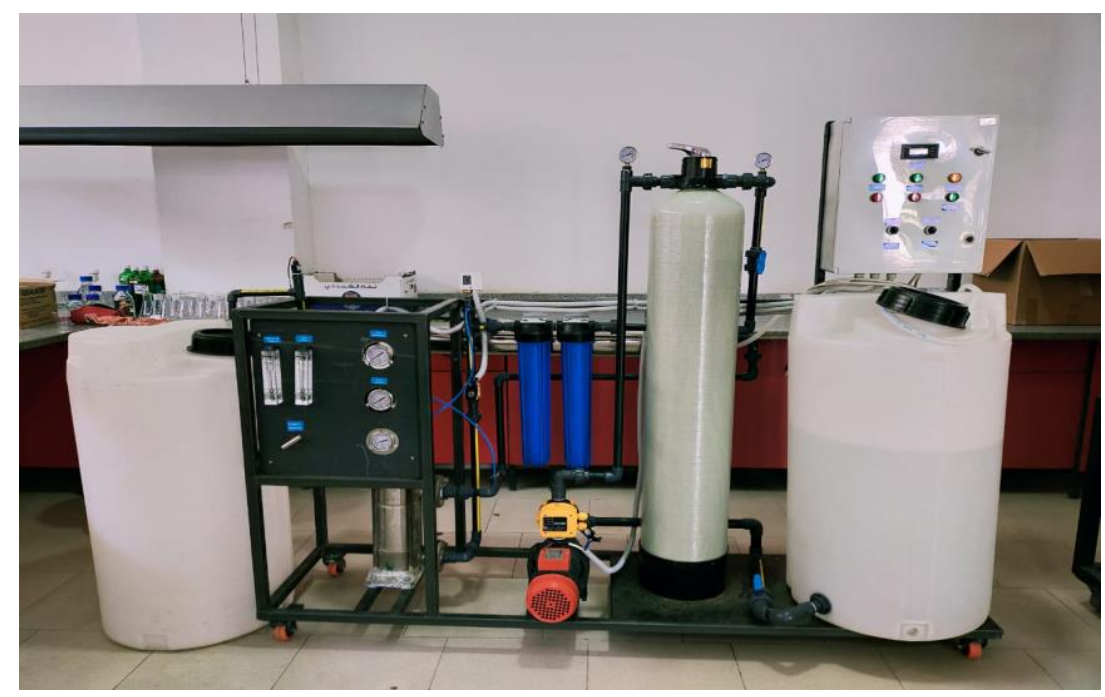

Figure 4 Reverse Osmosis desalination plant

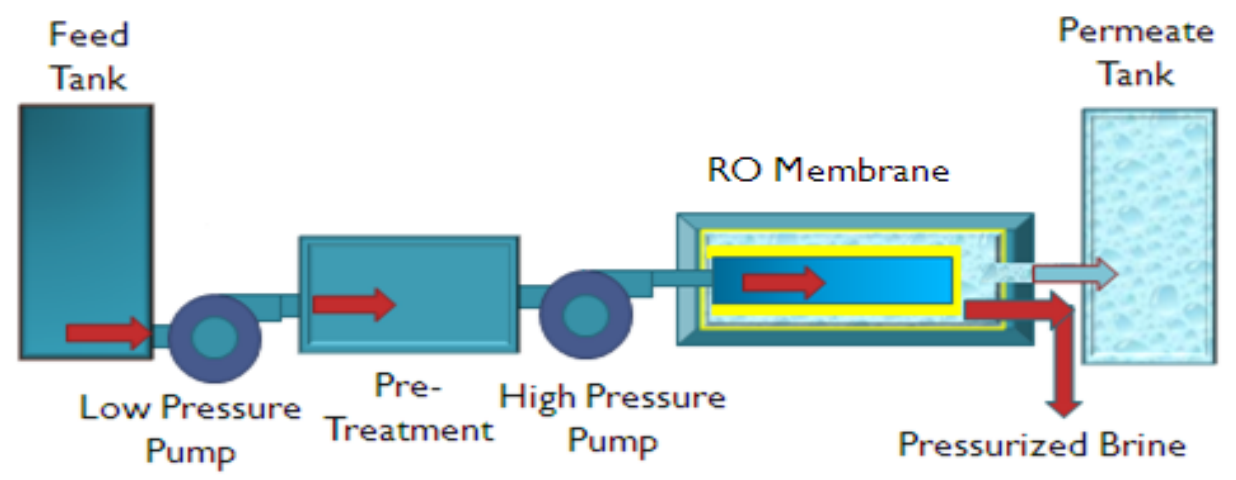

Figure 5 Flow diagram of RO desalination plant

\subsection{Experimental Procedures}

Two sets of experiments were achieved through this research; the first set includes ground water desalination of different inflow TDS that range from $2000 \mathrm{ppm}$ to $10000 \mathrm{ppm}$, through these runes we have investigated the effect of temperature (coastal zone temperature), TDS and pressure on the permeate flow rate, permeate salt concentration (TDS), energy consumption, salt rejection percent and the recovery percent, examples for resulted data can be shown in tables 1 and 2. The flow permeate were constant for all runs $\left(1 \mathrm{~m}^{3} /\right.$ hour).

Table 2 Experimental results for BW 3040/40, active area $37 \mathrm{~m} 2$, recovery (50\%), constant temperature $\left(19^{\circ} \mathrm{C}\right)$ and constant feed flow rate $(2 \mathrm{~m} 3 / \mathrm{hr})$

\begin{tabular}{ccccccc}
\hline $\begin{array}{c}\text { Concentrati } \\
\text { on }(\mathbf{p p m})\end{array}$ & $\begin{array}{c}\text { Permeate } \\
\text { Flow Rate } \\
(\mathbf{m} \mathbf{3} / \mathbf{h r})\end{array}$ & $\begin{array}{c}\text { Permeate Flux } \\
(\mathbf{L} / \mathbf{m} \mathbf{2 . h r})\end{array}$ & $\begin{array}{c}\text { TDS } \\
(\mathbf{p p m})\end{array}$ & $\begin{array}{c}\text { Salt } \\
\text { Rejection } \\
\mathbf{\%}\end{array}$ & $\begin{array}{c}\text { pressur } \\
\text { e(bar) }\end{array}$ & $\begin{array}{c}\text { Specific Energy } \\
(\mathbf{k W . h r} / \mathbf{m 3})\end{array}$ \\
\hline 2000 & 1 & 27.0270270 & 17.8 & 99.11 & 15.30 & 1.06 \\
3000 & 1 & 27.0270270 & 30 & 99 & 17.00 & 1.18 \\
4000 & 1 & 27.0270270 & 42 & 98.95 & 18.80 & 1.31 \\
5000 & 1 & 27.0270270 & 53 & 98.94 & 20.00 & 1.39 \\
6000 & 1 & 27.0270270 & 63 & 98.95 & 22.30 & 1.55 \\
7000 & 1 & 27.0270270 & 74 & 98.94 & 23.70 & 1.65 \\
8000 & 1 & 27.0270270 & 84 & 98.95 & 25.00 & 1.74 \\
9000 & 1 & 27.0270270 & 95 & 98.94 & 27.70 & 1.92 \\
10000 & 1 & 27.0270270 & 104 & 98.96 & 29.00 & 2.01 \\
\hline
\end{tabular}


Table 3 Experimental results for BW 3040/40, active area $37 \mathrm{~m} 2$, recovery (50\%), constant temperature $\left(20.4^{\circ} \mathrm{C}\right)$ and constant feed flow rate $(2 \mathrm{~m} 3 / \mathrm{hr})$

\begin{tabular}{ccccccc}
\hline $\begin{array}{c}\text { Concentratio } \\
\mathbf{n}(\mathbf{p p m})\end{array}$ & $\begin{array}{c}\text { Permeate } \\
\text { Flow Rate } \\
(\mathbf{m} \mathbf{3} / \mathbf{h r})\end{array}$ & $\begin{array}{c}\text { Permeate Flux } \\
(\mathbf{L} / \mathbf{m} \mathbf{2} \mathbf{h r})\end{array}$ & $\begin{array}{c}\text { TDS } \\
(\mathbf{p p m})\end{array}$ & $\begin{array}{c}\text { Salt } \\
\text { Rejection } \\
\mathbf{\%}\end{array}$ & $\begin{array}{c}\text { pressure } \\
(\mathbf{b a r})\end{array}$ & $\begin{array}{c}\text { Specific Energy } \\
(\mathbf{k W . h r} / \mathbf{m 3})\end{array}$ \\
\hline 2000 & 1 & 27.0270270 & 19 & 99.05 & 14.50 & 1.01 \\
3000 & 1 & 27.0270270 & 32 & 98.9333 & 16.30 & 1.13 \\
4000 & 1 & 27.0270270 & 45 & 98.875 & 18.00 & 1.25 \\
5000 & 1 & 27.0270270 & 57 & 98.86 & 19.80 & 1.38 \\
6000 & 1 & 27.0270270 & 69 & 98.85 & 21.50 & 1.49 \\
7000 & 1 & 27.0270270 & 80 & 98.8571 & 23.00 & 1.60 \\
8000 & 1 & 27.0270270 & 91 & 98.8625 & 25.00 & 1.74 \\
9000 & 1 & 27.0270270 & 102 & 98.8666 & 26.50 & 1.84 \\
10000 & 1 & 27.0270270 & 113 & 98.87 & 28.70 & 1.99 \\
\hline
\end{tabular}

The second set of the experiments was the sea water desalination for sea water TDS of $39000 \mathrm{ppm}$, , through these runes we have investigated the effect of temperature (coastal zone temperature and pressure on the permeate flow rate, permeate salt concentration (TDS), energy consumption, salt rejection percent and the recovery percent, examples for resulted data can be shown in tables 3 . Also the flow permeate were constant for all runs $\left(1 \mathrm{~m}^{3} /\right.$ hour $)$ as set no 1 .

Table 4 Experimental results for SW30XHR-440i, active area $40.9 \mathrm{~m} 2$, constant feed concentration (39000 ppm)

\begin{tabular}{ccccccc}
\hline $\begin{array}{c}\text { Feed } \\
\text { Temp } \\
\left({ }^{\circ} \mathbf{C}\right)\end{array}$ & $\begin{array}{c}\text { Permeate } \\
\text { Flow Rate } \\
(\mathbf{m} \mathbf{3} / \mathbf{h r})\end{array}$ & $\begin{array}{c}\text { Permeate Flux } \\
(\mathbf{L} / \mathbf{m} \text { 2.hr })\end{array}$ & $\begin{array}{c}\text { TDS } \\
(\mathbf{p p m})\end{array}$ & $\begin{array}{c}\text { Salt } \\
\text { Rejection } \\
\mathbf{\%}\end{array}$ & $\begin{array}{c}\text { Pressure } \\
(\mathbf{b a r})\end{array}$ & $\begin{array}{c}\text { Specific } \\
\text { Energy } \\
(\mathbf{k W . h r} / \mathbf{m})\end{array}$ \\
\hline 19 & 1 & 24.44987775 & 56 & 99.85641 & 79.00 & 21.09 \\
20.3 & 1 & 24.44987775 & 61 & 99.84358 & 76.00 & 20.29 \\
20.4 & 1 & 24.44987775 & 61 & 99.84358 & 76.00 & 20.29 \\
23.5 & 1 & 24.44987775 & 71 & 99.81794 & 72.00 & 19.23 \\
24.8 & 1 & 24.44987775 & 77 & 99.80256 & 71.00 & 18.96 \\
28.3 & 1 & 24.44987775 & 92 & 99.76410 & 68.00 & 18.16 \\
29.2 & 1 & 24.44987775 & 97 & 99.75128 & 67.00 & 17.89 \\
32 & 1 & 24.44987775 & 112 & 99.71282 & 66.00 & 17.62 \\
32.6 & 1 & 24.44987775 & 116 & 99.70256 & 65.50 & 17.49 \\
33.9 & 1 & 24.44987775 & 123 & 99.68461 & 65.00 & 17.36 \\
34.2 & 1 & 24.44987775 & 125 & 99.67948 & 65.00 & 17.36 \\
34.7 & 1 & 24.44987775 & 128 & 99.67179 & 64.30 & 17.17 \\
\hline
\end{tabular}

\subsection{Experimental Results and Analysis}

The experimental results for set no 1 are shown in figures 6 to 10, figure 6 represents feed water pressure versus feed water TDS for different temperatures, the results indicated that the feed water pressure increased under the effect of the increasing inflow water TDS, but on other hand the increasing of feed water temperature decreased the required pressure due to the fact that the water temperature enlarges membrane voids that allows water to pass through it easily. Referring to figure 7 that represents permeate water TDS versus feed water TDS for different temperatures, the results indicated that the permeate water TDS increased under the effect of the increasing inflow water TDS, also the increasing of feed water temperature increased the effluent TDS due to the fact that the water temperature enlarges membrane voids that allows more salts to pass through these voids. 
Figure 8 represents salt rejection percent versus feed water TDS for different temperatures, the results indicated that the salt rejection percent decreased under the effect of the increasing inflow water TDS, at the same time the increasing of feed water temperature decreased the salt rejection percent due to the fact that the water temperature allows more salts to pass through the membrane. Regarding figure 9 that represents energy consumption versus feed water TDS for different temperatures, the results indicated that the energy consumption increased under the effect of the increasing inflow water TDS, while the increasing of feed water temperature decreased energy consumption as a result of heat energy flux that was gained by water temperature.

Figure 10 represents permeate flow rate versus feed water TDS for different temperatures, we can see from the chart that the permeate flow rate is constant for all runs for all water temperatures because we fixed it at $1 \mathrm{~m}^{3} /$ hour as we mentioned before in the experimental procedures. The experimental results for set no 2 are shown in figures 11 to 15 , figure 11 represents feed water pressure versus feed sea water temperatures of TDS $39000 \mathrm{ppm}$, the results indicated that the feed water pressure decreased under the effect of the feed water temperature due to the fact that the water temperature enlarges membrane voids to allow water to pass with less pressure. Referring to figure 12 that represents permeate water TDS versus sea water temperatures, the results indicated that the permeate water TDS increased under the effect of the of feed water temperature, this happened because of the enlargement of membrane voids under the effect of temperature that allows more salts to pass through it.

Figure 13 represents salt rejection percent versus feed water temperature for, the results indicated that salt rejection percent decreased under the effect of the increasing of inflow water temperature due to the fact that the water temperature allows more salts to pass through the membrane easily. Referring to figure 14 that represents specific energy consumption versus feed water temperatures, the results indicated that the increasing of feed water temperature decreased energy consumption as a result of heat energy flux that was gained by water temperature. Figure 15 represents permeate flow rate versus feed water temperatures, we can see from the chart that the permeate flow rate is constant for all runs for all water temperatures because we fixed it at $1 \mathrm{~m}^{3} /$ hour as we mentioned before in the experimental procedures.

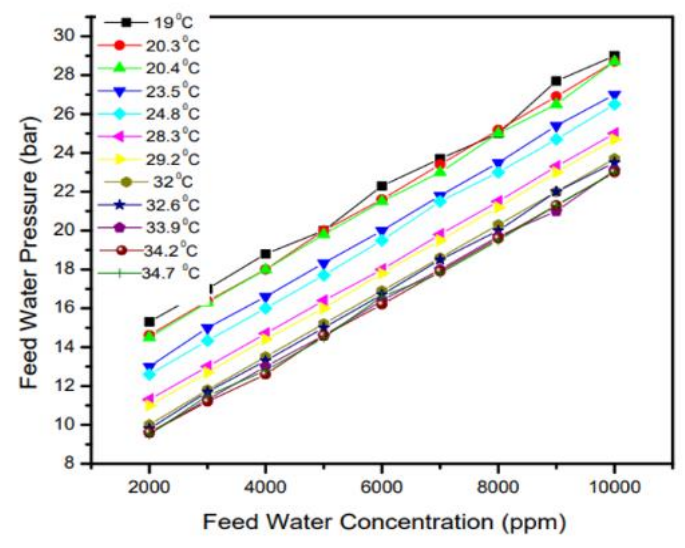

Figure 6 Feed water pressure versus versus feed water concentration

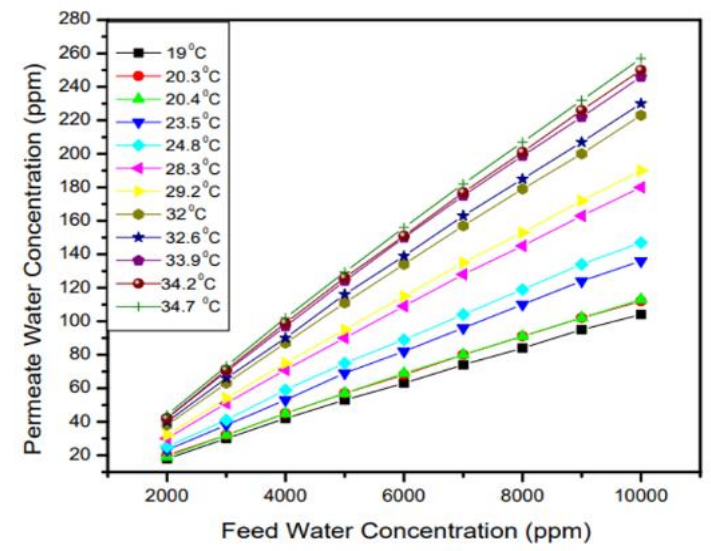

Figure 7 Permeate water concentration feed water concentration 


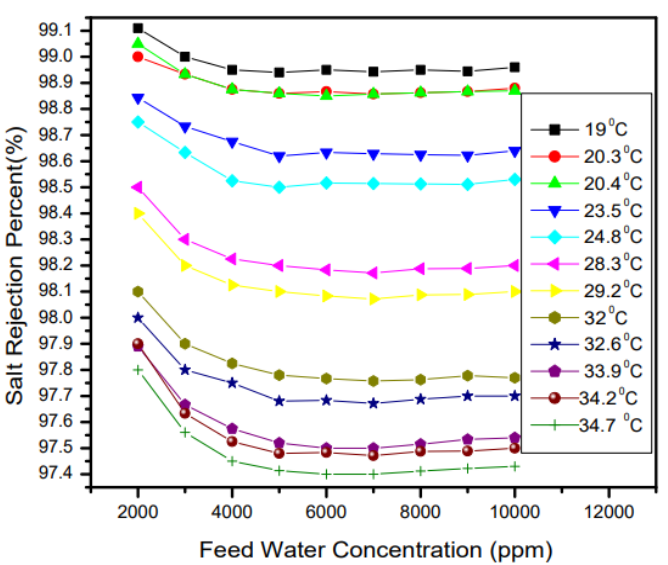

Figure 8 Salt rejection percent versus feed water concentration

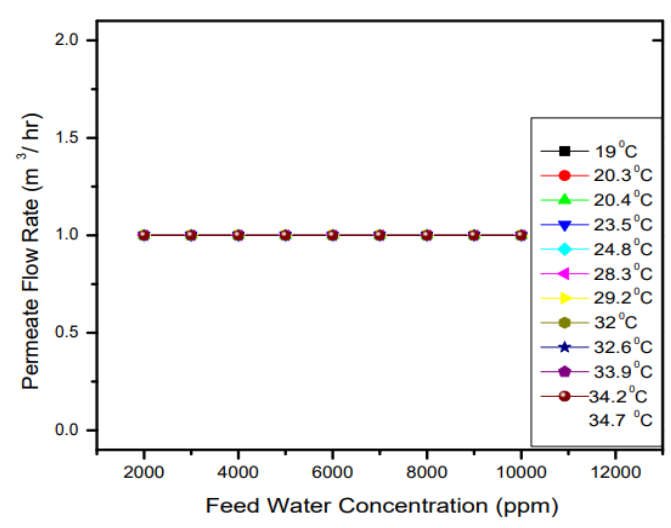

Figure 10 Permeate flow rate versus Feed water concentration

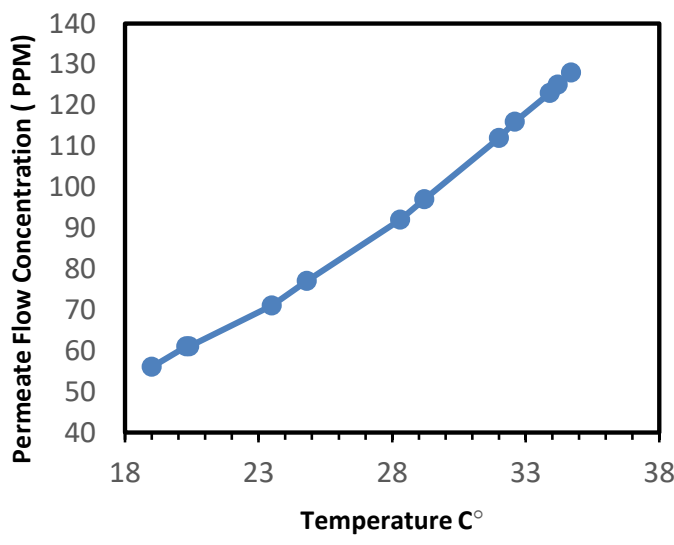

Figure 12 Permeate water concentration versus feed water temperature

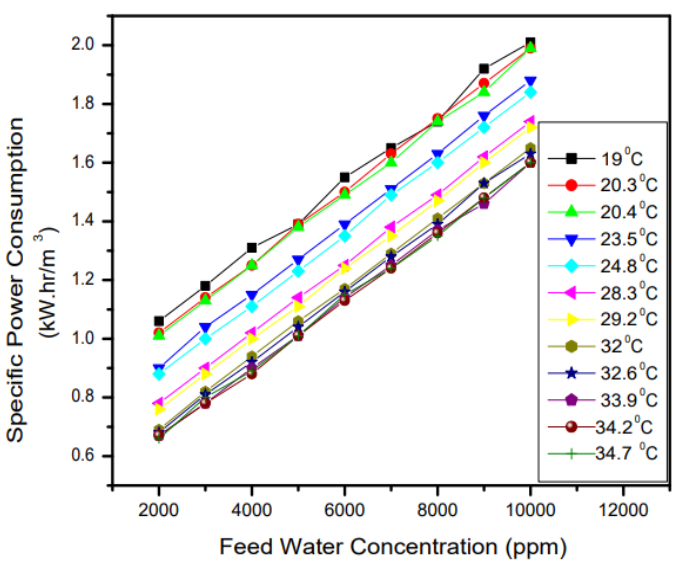

Figure 9 Specific power consumption versus feed water concentration

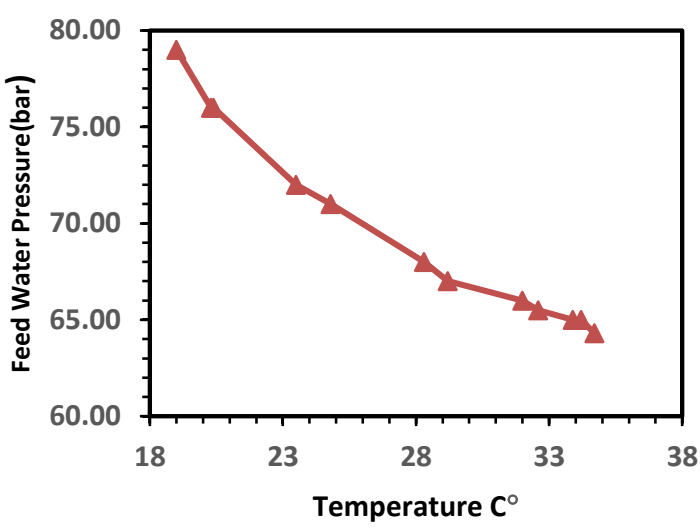

Figure 11 Feed water pressure versus feed water temperature

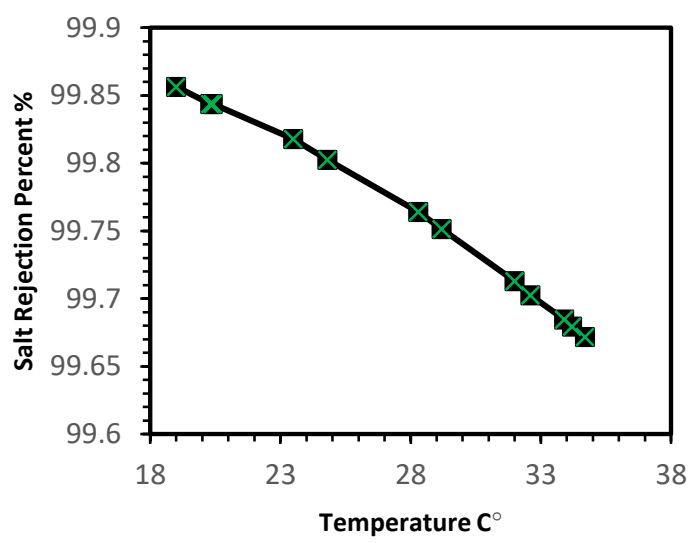

Figure 13 Salt rejection percent versus feed water temperature 


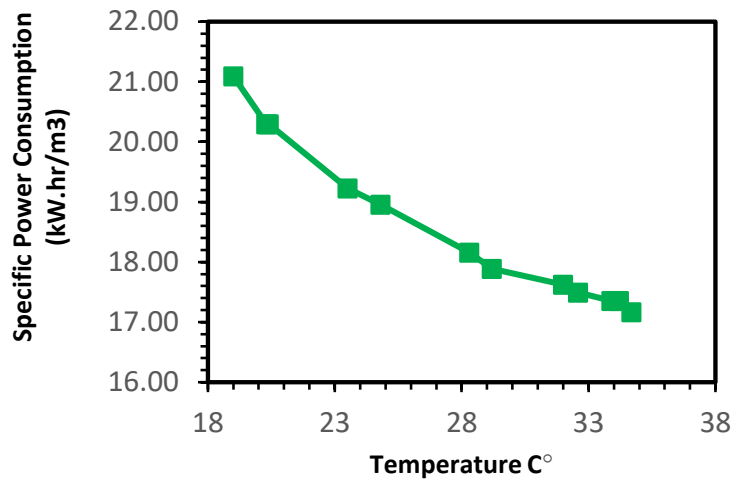

Figure 14 Specific power consumption versus feed water temperature

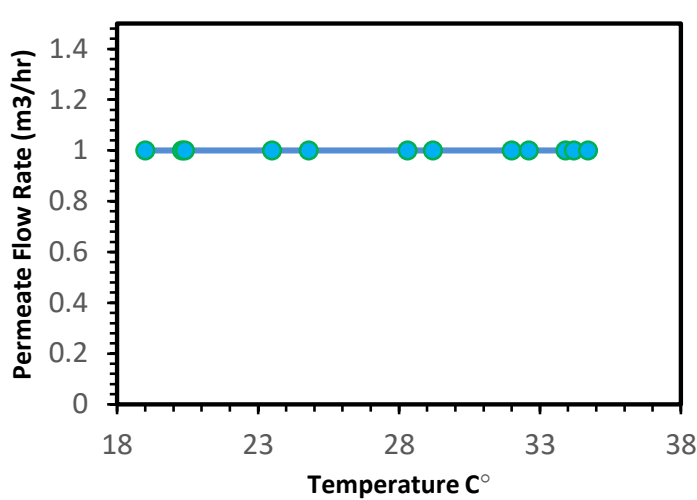

Figure 15 Permeate flow rate versus feed water temperature

\section{COST ANALYSIS}

All the following calculations are based on life time of 20 years for this desalination plant.

\subsection{Total Costs}

It includes all construction, components, and equipment used in the plant. It is calculated by summing the prices of all of these components. The operating and maintenance $(O \& M)$ costs consist of fixed costs and variable costs. No fixed costs exist in the present project. The point of view here is the variable costs, which include labor, energy, chemical, and maintenance costs. Labors and chemicals are not required to operate this plant, therefore no labor costs and chemical costs should be taken into consideration in our calculations. The cost for maintenance and spare parts is typically less than $5 \%$ of the total capital cost on an annual basis as shown in table 5[10].

Table 5 Total Costs Calculations

\begin{tabular}{clc}
\hline \multicolumn{2}{c}{ Total Capital Costs Calculations } \\
\hline Item & \multicolumn{1}{c}{ Description } & Price (LE) \\
\hline 1 & Pressure Vessel 4021 & 700 \\
2 & Membrane Element BW30-4040 & 3500 \\
3 & 2 Feed Pump 1 HP & 3000 \\
4 & 2 High Pressure Pump 1.5 HP & 11500 \\
5 & Electrical control panel & 2025 \\
6 & Main Body & 2850 \\
7 & 2Tanks & 1060 \\
8 & Multimedia Filter 10*54 & 1800 \\
9 & Manual Control Head & 150 \\
10 & Carbon & 120 \\
11 & Sand & 100 \\
12 & 2 Cartridge Filter Housing 3/4*20 & 390 \\
13 & 4 Brackets for Cartridge Filters & 175 \\
14 & 2 Flowmeter Panel Mounted 5 GPM & 600 \\
15 & 2 Conductivity meter & 600 \\
16 & Pipes, Connections, and Fittings & 1430 \\
\hline Capital Cost & 30000 \\
Maintenance cost per 10 years & 15000 \\
Operation cost per 10 years & Variable based on water TDS \\
Total cost per 10 years & $45000+$ Operation cost \\
\hline
\end{tabular}

The total cost $(\mathrm{LE} /$ day $)=$ Total cost per 10 years $/(10$ years $\times 12$ months $\times 30$ days $)$ 


\subsection{Desalinated Water Costs}

The present desalination plant capacity is $24 \mathrm{~m}^{3} /$ day where the permeate flow rate about $1000 \mathrm{~L} /$ hour with inlet feed water concentration range from 2000 to $10000 \mathrm{ppm}$ and the feed pressure is variable.

Actual costs of cubic meter of desalinated water $\left(\mathrm{LE} / \mathrm{m}^{3} /\right.$ day $)=$ total cost per day

plant capacity (m3/ day)

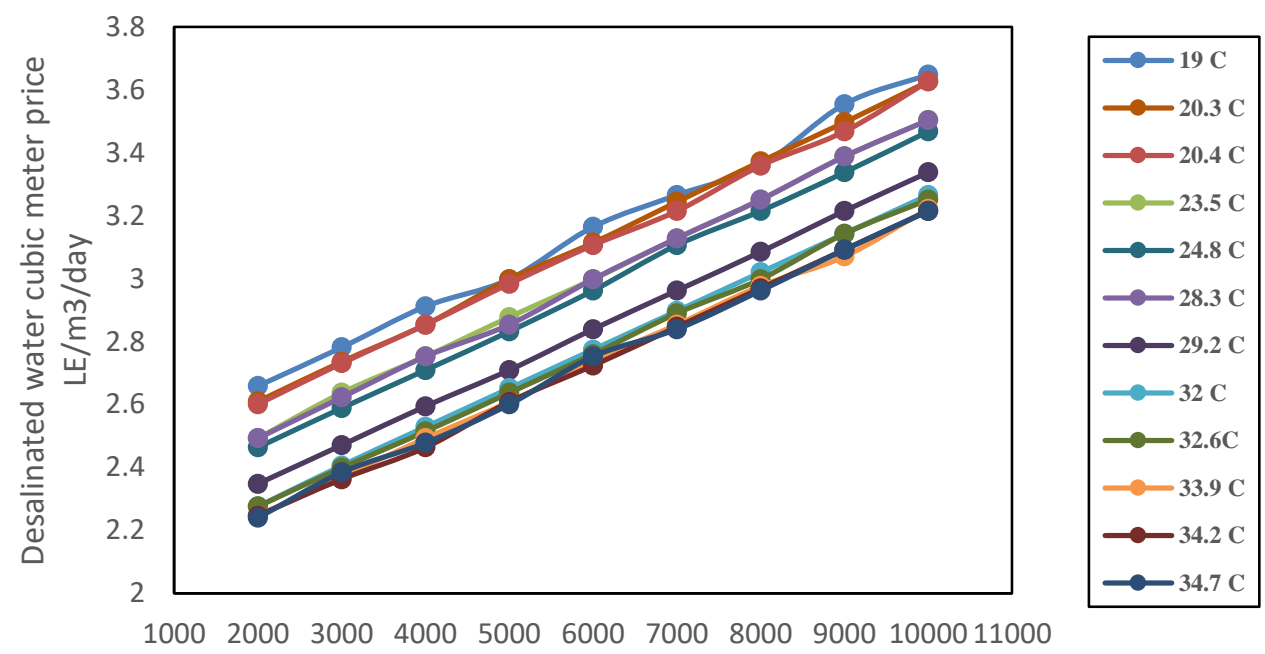

Feed water concentration (PPM)

Figure 16 Desalinated water cubic meter price versus feed water TDS for one feddan

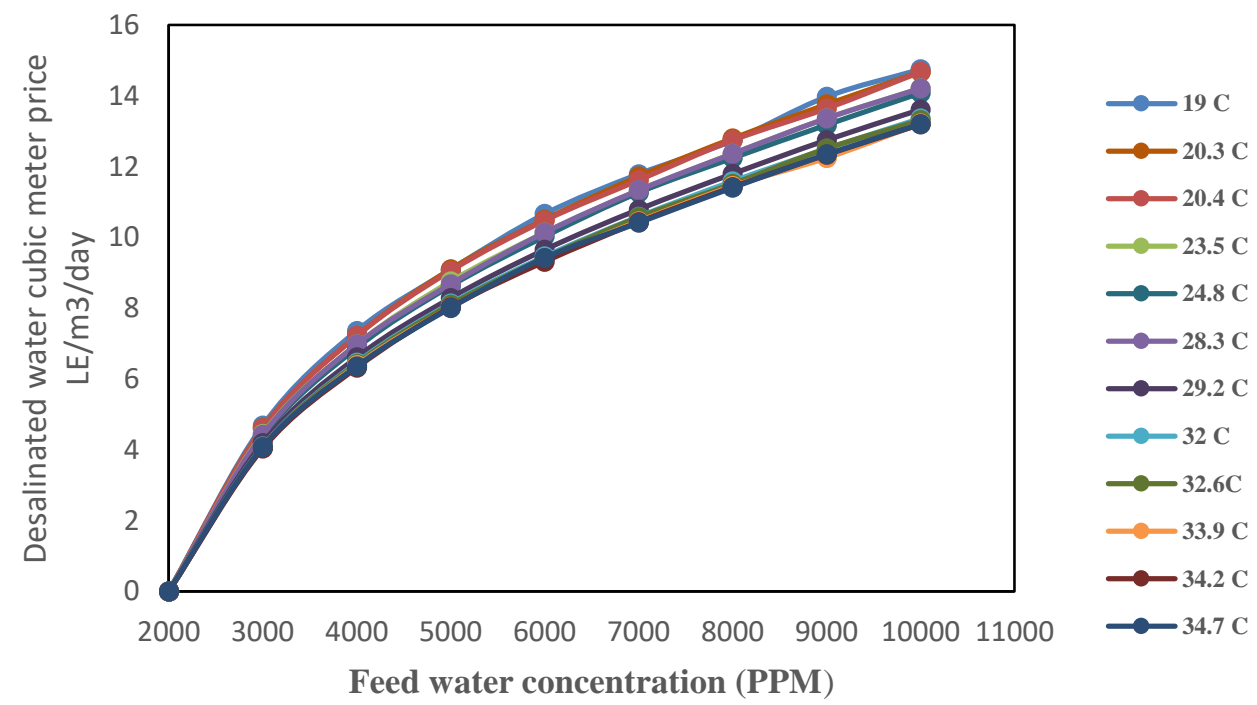

Figure 17 Desalinated water cubic meter price versus feed water TDS after mixing with brakish water for the whole area (5 feddans)

As it shown in the figure 16 which represents desalinated cubic meter price versus feed water TDS that the cubic meter price is directly proportional to the water TDS, this resulted from the fact that the increasing of the water TDS will increase the required energy to desalinate it, while the cubic meter price is inversely proportional to the water temperature due to the fact that the increasing of water temperature will decrease the required membrane pressure, also we find out that the cubic meter price for the whole area (5 feddans) will range 
from $4 \mathrm{LE}$ to $14.67 \mathrm{LE}$ ( from $\$ 0$ to $\$ 0.92$ per $\mathrm{m} 3$ ) as it shown in figure 17 , this cubic meter price is resulted from mixing the desalinated water with other amount of brackish water. This result is compatible with the Texas Water Development Board which estimated that the total production cost of desalinating brackish groundwater ranged from $\$ 0.29$ to $\$ 0.66$ per m3 of capacity (\$1.09 to $\$ 2.49$ per thousand gallons) (Arroyo, et al., 2012)[11].

\section{CONCLUSIONS}

- The feed water pressure increased under the effect of the increasing inflow water TDS, but on other hand the increasing of feed water temperature decreased the required pressure due to the fact that the water temperature enlarges membrane voids that allows water to pass through it easily

- The permeate water TDS increased under the effect of the increasing inflow water TDS, but the increasing of feed water temperature increased the effluent TDS due to the fact that the water temperature enlarges membrane voids that allows more salts to pass through these voids.

- The salt rejection percent decreased under the effect of the increasing inflow water TDS, at the same time the increasing of feed water temperature decreased the salt rejection percent due to the fact that the water temperature allows more salts to pass through the membrane

- The energy consumption increased under the effect of the increasing inflow water TDS, while the increasing of feed water temperature decreased energy consumption as a result of heat energy flux that was gained by water temperature.

- The cubic meter price is directly proportional to the water TDS due to the fact that the increasing of the water TDS will increase the required energy.

- The cubic meter price is inversely proportional to the water Temperature due to the fact that the increasing of water temperature will decrease the required membrane pressure

- The cubic meter price for the whole area (5 feddans) will range from 4 LE to 14.67 LE (from $\$ 0$ to $\$ 0.92$ per $\mathrm{m} 3$ )

\section{ACKNOWLEDGEMENTS}

The authors thank Engs Abdel Rahman Mohamed, Seif El Deen Maged and Talal Magdy for their valuable help in the building of the model, also The authors thank the University board of trustees for their encouragement to conduct such studies for the benefit of science and society .

\section{REFERENCES}

[1] World Bank, The World Bank participation sourcebook (English). Washington, D.C.: The World Bank. 1996.

[2] https://www.worldatlas.com.

[3] http://www.eeaa.gov.eg/en-us/topics/management/iczm.aspx.

[4] http://www.map-library.com/maps/maps-of-africa/maps-of-egypt/large-based-map-ofegypt.jpg

[5] Soliman A.M.M., Solimsn M.M, Groundwater Potential in the New Valley South West of the Nile Delta in Egypt. In: Negm A. (eds) Groundwater in the Nile Delta. The Handbook of Environmental Chemistry, 2017, vol 73. Springer, Cham. 
[6] Sharaky A.M., El Hassanein A.S., Atta S.A., Khallaf K.M.A, Salinization and Origin of the Coastal Shallow Groundwater Aquifer, Northwestern Nile Delta, Egypt. In: Negm A. (eds) Groundwater in the Nile Delta. The Handbook of Environmental Chemistry, 2017, vol 73. Springer, Cham.

[7] Raza, Moonis, Geographical Dictionary of the World in the Early 20th Century with Pronouncing Gazetteer . Concept Publishing Company, 1990, ISBN 978-81-7268-011-4.

[8] http://www.fao.org/3/t0234e/t0234e01.htm.

[9] Amin, M., Bazedi, G., Design of Reverse Osmosis Desalination Plant in Suez City (Case Study). The Journal of Scientific and Engineering Research. 3. 2016, pp. 149-156.

[10] Ismail, I., Water Desalination in Egypt, 2018. 10.13140/RG.2.2.24618.11201.

[11] Arroyo J, et al. (2011) Functional and genomic analyses of blocked protein O-mannosylation in baker's yeast. Mol Microbiol 79(6):1529-46 